\title{
ABORTO E CORPORALIDADE: SOFRIMENTO E VIOLÊNCIA NAS DISPUTAS MORAIS ATRAVÉS DE IMAGENS*
}

\author{
Naara Luna \\ Universidade Federal Rural do Rio de Janeiro - Brasil
}

Resumo: $O$ artigo analisa representações do aborto por meio do discurso e imagens contidas em documentários. Na controvérsia do aborto no espaço público, grupos alinhados pró-vida e pró-escolha buscam o audiovisual como meio de propagar suas mensagens políticas. A retórica visual pró-vida recorre a imagens de diferentes estágios do desenvolvimento para provar a individualidade de embriões e fetos e sua condição de pessoa dotada de direitos. O movimento pró-escolha constrói seu discurso por meio de relatos de pessoas que passaram pela experiência do aborto, enfatizando o sofrimento e a violência da criminalização e da clandestinidade. $O$ foco é a mulher como sujeito moral. A exceção está no tópico da anencefalia, quando imagens são usadas para representar a figura do "bebê sem cérebro" inviável. A partir do sofrimento e da violência, fetos e mulheres são apresentados como vítimas pelos diferentes lados da disputa, modo de reivindicar acesso a direitos.

Palavras-chave: aborto, imagem, pessoa, sofrimento.

Abstract: The article analyses representations of abortion through discourse and images present in documentaries. Pro-life and pro-choice parties use audiovisual as means to diffuse their political messages in abortion controversy taking place in public space. Pro-life visual rhetoric uses images of different stages of development in order to prove the individuality of embryo and fetus and their status of person bearer

* Artigo baseado na comunicação "Aborto e corporalidade: as disputas morais através de imagens" apresentada no GT31 - Saúde, emoção e moral do $36^{\circ}$ Encontro Anual da Anpocs, em Águas de Lindóia (SP), outubro de 2012. Este artigo integra o projeto "Do aborto à pesquisa com células-tronco embrionárias: o estatuto de embriões e fetos e o debate sobre direitos humanos no Brasil", pesquisa financiada com o Auxílio APQ-1 da Faperj. Representa um resultado do "Laboratório Análise de Imagem e Texto na Mídia: um Estudo de Caso" realizado com estudantes de Ciências Sociais da UFRRJ.

Horizontes Antropológicos, Porto Alegre, ano 20, n. 42, p. 293-325, jul./dez. 2014 http://dx.doi.org/10.1590/S0104-71832014000200012 
of rights. Pro-choice movement builds a discourse through narratives of people who experienced abortion, emphasizing the suffering and violence of criminalization and clandestinity. The focus is the woman as a moral subject. The exception regards anencephaly, when images are used to represent the figure of an unviable brainless baby. Based on suffering and violence experiences, fetuses and women are presented as victims by different sides of the dispute, a way to claim rights.

Keywords: abortion, image, personhood, suffering.

\section{Introdução}

$\mathrm{O}$ artigo analisa representações do aborto por meio do discurso e imagens contidos em documentários, o que responde à necessidade surgida no trabalho de campo, uma vez que os atores sociais frequentemente recorrem a imagens para ganhar as disputas políticas e lançar argumentos de caráter moral. A controvérsia do aborto no espaço público é construída de forma polar por grupos alinhados com as perspectivas pró-vida e pró-escolha que buscam o audiovisual como meio de propagar suas mensagens políticas. A retórica visual pró-vida recorre a imagens de diferentes estágios do desenvolvimento para provar a individualidade de embriões e fetos e sua condição de pessoa dotada de direitos. A corporeidade também aparece na visualização de intervenções cirúrgicas e de seus restos. Por outro lado, o movimento pró-escolha constrói seu discurso por meio de relatos e histórias de pessoas que passaram pela experiência do aborto. Nesse sentido, a imagem da mulher como sujeito moral que toma decisões vem para primeiro plano. A exceção seria quando se aborda o tópico da anencefalia, em que a imagem ultrassonográfica ou as próprias fotografias são usadas para representar a figura do "bebê sem cérebro" totalmente inviável. Fetos e mulheres são apresentados como vítimas pelos diferentes lados da disputa, outro modo de reivindicar acesso a direitos que lhes seriam negados. Os filmes são criados como armas para disputas políticas, construídos para despertar emoções de solidariedade e indignação.

Os filmes pró-escolha foram selecionados nos sites das ONGs feministas Anis e Ipas, exibidos no cinema, ou obtidos em encontros de ciências sociais. O objetivo dessa seleção foi obter o máximo possível de documentários brasileiros sobre aborto, porque se cria que o material antiaborto seria mais numeroso.

Horizontes Antropológicos, Porto Alegre, ano 20, n. 42, p. 293-325, jul./dez. 2014 
A busca aleatória de filmes sobre o aborto pela internet resulta em links para produções curtas e muito semelhantes que mostram apenas a expulsão. Fez-se a busca em entidades pró-vida para garantir que o audiovisual tivesse recepção no movimento. Dois filmes feitos nos Estados Unidos e a projeção de slides para palestra pró-vida eram material disponível no site do Movimento em Defesa da Vida da Arquidiocese do Rio de Janeiro, e o filme A dura realidade (Hard truth, 1991) foi distribuído pela Associação Pró-Vida e Pró-Família. Localizou-se o filme Flores de Marcela (2009) no YouTube.

Observou-se em diversos eventos públicos centrados no debate sobre aborto o uso de imagens pelo movimento antiaborto: pôsteres em julgamentos, solenidades e missas em celebração do nascituro. As imagens constituem tipo de discurso.

O presente artigo tem fundamentação teórica em duas vertentes distintas: a da antropologia da pessoa, corpo e saúde, em particular no enfoque sobre o estatuto do feto e do embrião e o debate sobre direitos humanos. A segunda vertente compreende a análise do material audiovisual com o objetivo de revelar as dimensões de sofrimento e violência no contexto do aborto, a partir dos relatos de mulheres apresentados nos filmes construídos na perspectiva pró-escolha (favorável à legalização) ou na perspectiva antiaborto ou pró-vida. Víctora (2011, p. 5) ao caracterizar o sofrimento quer "mostrar que diferentes tempos e sociedades produzem certos tipos de sofrimento, que são experimentados no corpo, ou seja, corporificados, na medida em que o corpo é o locus de produção e atualização constante dos sentidos". Para abordar a temática do sofrimento, reporto-me aqui ao trabalho de Veena Das que traz reflexões sobre gênero e violência a partir da memória de mulheres que viveram o processo histórico de partição da Índia. Diante de situações de abuso e violência extremada, a experiência do sofrimento de muitas mulheres foi colocada na esfera do indizível: a reconstrução da vida cotidiana e das relações de parentesco implicava deixar o trabalho do tempo cicatrizar dores e feridas (Das, 1999). A autora quer explorar o significado de testemunhar essa violência (Das, 2011).

Pollak (1989) analisa diferentes tipos de memórias que são caladas e afloram, a partir dos exemplos das lembranças proibidas dos crimes estalinistas após a abertura do regime soviético, das lembranças indizíveis de judeus sobreviventes de campos de concentração que retornaram a seu lugar de origem, e as lembranças vergonhosas dos alsacianos recrutados à força por diferentes lados na história da região. 
A fronteira entre o dizível e o indizível, o confessável e o inconfessável, separa, em nossos exemplos, uma memória coletiva subterrânea da sociedade civil dominada ou de grupos específicos, de uma memória coletiva organizada que resume a imagem que uma sociedade majoritária ou o Estado desejam passar e impor. (Pollak, 1989, p. 8).

Os documentários examinados pretendem colocar em discurso o que era indizível, porque vergonhoso, clandestino ou ilegal.

Discutindo a experiência de tornar-se sujeito, Veena Das (2011) argumenta que o significado de testemunhar a violência constitui processos de subjetivação. Ela analisa a figura de Antígona como testemunha em termos de mito fundador de uma consciência com voz no feminino na imaginação literária do Ocidente. Na peça Antígona, ocorre o confronto de Antígona e seu irmão Creonte, governante da cidade de Tebas, que a condena ao emparedamento viva por ter celebrado os ritos funerários do irmão Polinice, considerado traidor da cidade-estado. Das (2011, p. 14) considera que a denúncia de Antígona mostra "a criminalidade da própria ordem social". O enfoque da autora indiana está no trabalho do luto e na reconstrução das vidas no quadro das relações de parentesco. O não dito torna-se obrigatório para a reconstrução da vida no contexto indiano descrito. Inspirada por seu aporte, gostaria de colocar esse questionamento no contexto do problema do aborto, considerando como este é construído nas narrativas audiovisuais pró-escolha e nas antiaborto. Os dois lados apontam para a "criminalidade da regra social". Na perspectiva da militância antiaborto, autodenominada pró-vida, a legalidade de qualquer aborto é questionada como criminosa. Isso vale tanto para o contexto brasileiro, no qual há apenas as situações de não punibilidade nos casos de gestação decorrente de estupro ou se não há outro meio de salvar a vida da mãe (artigo 128 do Código Penal), com o acréscimo recente da antecipação de parto de anencéfalo após o julgamento da ADPF 54 pelo Supremo Tribunal Federal, ${ }^{1}$ mas vale também para o contexto dos Estados Unidos, onde a interrupção voluntária da gravidez é legal (cf. Dworkin, 2003). A criminalização do aborto no Brasil coloca a prática na clandestinidade ou implica a autorização judicial em casos específicos. Afirmo que, para se contrapor ao indizível, a produção audiovisual vai "dar testemunho da criminalidade da regra social" (Das, 2011, p. 15).

1 Arguição de Descumprimento de Preceito Fundamental 54, julgada em 11/04/2012.

Horizontes Antropológicos, Porto Alegre, ano 20, n. 42, p. 293-325, jul./dez. 2014 
O agrupamento das experiências das mulheres nos documentários pró-escolha e a representação da morte fetal na produção audiovisual antiaborto mostram o sofrimento como "um processo social corporificado nos sujeitos históricos" (Víctora, 2011, p. 6). Víctora, fundamentada em Kleinman, Das e Lock (1997), relaciona uma dimensão importante do sofrimento social aos processos políticos e profissionais que podem envolver três tipos: 1) apropriações autorizadas ou contestadas do sofrimento coletivo; 2) medicalização da vida; 3) sofrimento nas relações políticas públicas. O terceiro modo referente às políticas públicas é bastante pertinente à presente análise: "políticas públicas que mesmo quando delineadas com o intuito de reduzir o sofrimento de pessoas e grupos historicamente desfavorecidos, podem intensificá-lo, através de efeitos intencionais e não intencionais" (Víctora, 2011, p. 7). Um exemplo é a teia burocrática característica dos órgãos públicos. A luta contra essa teia burocrática a fim de obter autorizações judiciais para aborto será vista adiante.

Pollak aborda o silêncio das vítimas dos campos de concentração internadas pela acusação de prostituição ou de homossexualidade. As vítimas temiam que a revelação dos motivos pudesse prejudicá-las no presente (Pollak, 1989). Para se contrapor a esse silêncio, a produção audiovisual aqui retratada pretende revelar o que estaria na esfera do indizível e visibilizar narrativas de eventos que ocorrem na clandestinidade. Boltanski (2012), em revisão da literatura antropológica sobre o aborto, aponta o caráter clandestino dessa prática, mesmo quando legalizada: suas características gerais seriam a universalidade nas sociedades, o fato de ser objeto de reprovação e ao mesmo tempo de tolerância, mas condenado ao um modo de existência vergonhoso.

No tocante à sua representação na sociedade brasileira, vários elementos

fazem do aborto um evento circunscrito à esfera privada da mulher e/ou casal, vivenciado algumas vezes na maior clandestinidade dentro de um sigilo que, em muitos casos, leva à negação absoluta de sua ocorrência, ainda nos casos em que requer tratamento hospitalar posterior. Comentar ou admitir a ocorrência de um aborto se circunscreve a contextos muito particulares, referência que se encontra claramente determinada pela vontade da mulher ou do homem de compartilhar essa experiência. (Ramírez-Galvez, 1999, p. 88-89).

A ilegalidade do aborto e a clandestinidade dessa prática o colocam na esfera do não dito em termos das experiências das pessoas que o vivenciaram. 
A produção audiovisual traz à tona essas vivências a fim de afetar o debate político e legal. Na definição de campo, diferentes grupos sociais estão envolvidos em uma luta simbólica para imporem a definição do mundo social mais conforme a seus interesses (Bourdieu, 1998). Quero demonstrar como ambos os lados constroem narrativas de sofrimento no audiovisual, representando situações de aborto que envolvem sofrimento e violência. Em ambas as perspectivas a construção da categoria de vítima (Sarti, 2011) pretende alcançar objetivos políticos.

\section{Os filmes}

Serão expostos primeiramente os filmes de orientação pró-escolha e depois os filmes pró-vida e a projeção de slides. ${ }^{2}$

\section{Filmes pró-escolha}

A descrição dos filmes seguirá a ordem cronológica do lançamento. Foram produzidos primeiramente filmes com relatos de mulheres gestantes de fetos com malformações incompatíveis com a vida e sua tentativa de obter autorização para interromper a gravidez, sendo os três primeiros dirigidos por Debora Diniz. Em seguida, dois outros filmes trazem relatos sobre diferentes experiências de aborto. $\mathrm{O}$ último filme pró-escolha transcende seus personagens principais, ao retratar um caso em que a demanda por realização do aborto causou comoção nacional. Nos documentários Habeas corpus (2005) e Direito \& saúde: o caso de Alagoinha (2010), é explicitada a interferência de agentes da hierarquia da Igreja Católica.

\section{Uma história Severina}

O documentário Uma história Severina (2005), de Debora Diniz e Elaine Brum, inaugura o ciclo. Retrata a história de Severina e seu marido, agricultores analfabetos da Zona da Mata de Pernambuco. Sua gestação teve o

2 Os financiamentos das diferentes produções audiovisuais são citados na versão original da comunicação.

Horizontes Antropológicos, Porto Alegre, ano 20, n. 42, p. 293-325, jul./dez. 2014 
diagnóstico de anencefalia fetal. Ela estava internada em um serviço de aborto legal na vigência da liminar concedida pelo ministro Marco Aurélio Mello referente à $\mathrm{ADPF} 54$ que permitia a antecipação do parto sem exigir outra autorização judicial, em 2004. A liminar foi cassada e Severina e seu marido Rosivaldo levaram três meses para obter a autorização para antecipar o parto. O documentário traz cenas gravadas pela TV Justiça da sessão em que foi cassada a liminar, com defesa do anencéfalo pelo ministro do STF Cézar Peluso e do então procurador-geral da República Claudio Fonteles. O documentário acompanha Severina quando ela obtém a autorização e vai para Recife. O casal mostra a ultrassonografia. Rosivaldo explica: é como se tivessem "torado" a parte de cima da cabeça do feto. Severina parte para fazer o aborto legal em um serviço em Recife. Uma integrante de ONG feminista a acompanha. Ela compra roupinhas para o bebê. Quando a vendedora oferece mais produtos, Severina responde que a criança não vai viver, nota-se o constrangimento da vendedora. Severina recebe a medicação para indução do parto e sofre várias horas de contrações com dor. A sogra a acompanha no parto. O bebê nasce morto. Severina chora, mas pede para ver. A sogra diz para ela ser forte e mostra a criança, embrulhada em lençol disfarçando a cabeça aberta na parte superior. Severina conta por celular ao marido que nasceu morto. O filme volta para a cidade deles e retrata o enterro. O sogro de Severina carrega o caixão minúsculo fechado e uma multidão segue. Severina e Rosivaldo não vão. Severina exibe uma foto do bebê de roupinha branca com gorro na cabeça. A cena final mostra a reação do casal ao documentário. Rosivaldo diz que só uma pessoa insensível não seria movida pelo filme.

O exemplo do anencéfalo, um feto que nasce com a cabeça aberta, sem estruturas como o cérebro, calota craniana e couro cabeludo, é o de um ente disforme. Embora o documentário seja bem discreto a respeito, remete-se aqui à análise de Bakhtin $(1999$, p. 38), “o aspecto essencial do grotesco é a deformidade”. O foco do filme está na experiência de dor da mulher como vítima e não no feto. A figura do anencéfalo evoca a análise de Foucault (2002, p. 69) sobre os anormais, especificamente na figura do monstro humano, "que constitui em sua existência mesma e em sua forma, não apenas uma violação das leis da sociedade, mas uma violação das leis da natureza”. Sendo uma violação das leis da natureza, desperta a curiosidade, o que se evidencia na grande frequência ao enterro.

Horizontes Antropológicos, Porto Alegre, ano 20, n. 42, p. 293-325, jul./dez. 2014 
Outro aspecto conceitual de relevo para a análise do conjunto de documentários diz respeito à noção de pessoa como indivíduo implicada: o indivíduo humano é o princípio das ideias centrais de igualdade e liberdade características dos valores modernos. Essas produções fílmicas representam o indivíduo como valor: o ser de razão, o sujeito normativo das instituições, segundo a formulação de Dumont (1997). Na perspectiva pró-vida, o feto é esse indivíduo, e na abordagem pró-escolha a mulher é o sujeito moral. Como sujeitos de direitos, Severina e Rosivaldo reivindicam autonomia de decidir quanto à continuidade de uma gestação inviável. Os ministros do STF que decidiram contra esse direito, julgaram ser o feto anencefálico o sujeito a defender. Esse embate será explicitado nas demais produções aqui analisadas.

\section{Habeas corpus}

O documentário Habeas corpus (2005), de Debora Diniz e Ramon Navarro, relata a história de uma mulher que, internada em hospital com autorização judicial para abortamento de feto com anomalia incompatível com a vida, foi impedida por um habeas corpus. O hospital já havia iniciado os procedimentos para indução de parto que foram interrompidos. O habeas corpus foi solicitado pelo padre Lodi ${ }^{3}$ para proteger a vida do nascituro. A primeira cena mostra Tatielle no hospital passando muito mal e amparada pelo marido e pela sogra. Em casa, o marido fala revoltado que um padre deve ter formação. Afirma que não é o padre que vai deitar ao lado da mulher e sentir sua barriga mexendo e saber que não tem vida. O padre não os conhece, nunca os visitou. Afirma que o padre tirou do casal uma chance de reduzir o sofrimento.

O documentário reconstitui o discurso dos médicos do hospital que a atenderam e de uma advogada. Vai do hospital para a casa da família, volta ao hospital e se encerra no cemitério.

A ênfase do documentário está no sofrimento da mulher que não foi abreviado pela antecipação do parto por conta do habeas corpus. Marido, irmã

3 O padre Lodi é do movimento antiaborto de Anápolis (GO).

Horizontes Antropológicos, Porto Alegre, ano 20, n. 42, p. 293-325, jul./dez. 2014 
e sogra se condoem com seu sofrimento físico: Tatielle tem muita dor e mal-estar. Outro aspecto grotesco é a exibição do feto que nasceu deformado.

Dois silêncios marcam esse documentário: um é do padre Lodi que entrou com o pedido de habeas corpus, mas não atendeu aos pedidos da produção para contar sua versão. O outro silêncio é o de Tatielle, tomada de dor. Todos falam, menos ela. Por outro lado, há uma forte afirmação de autonomia, expressão do princípio da liberdade característico da configuração individualista de valores (Dumont, 1997), por parte do marido de Tatielle que protesta contra a intervenção do padre. O marido e a sogra se perguntam como o padre soube do caso.

Diante do habeas corpus a favor do nascituro, os depoimentos dos profissionais de saúde e da família revelam a retração no atendimento. O médico que a atendeu explicita que o parto aconteceu de forma normal, talvez por efeito do início do tratamento para indução no hospital de Goiânia. Na exibição do sofrimento físico da gestante e nas queixas da família, em particular da irmã e do marido de Tatielle, o filme sugere uma situação de omissão de socorro: nada se fez para auxiliar a gestante, exceto iniciar o atendimento se o parto começasse espontaneamente.

$\mathrm{O}$ feto é descrito pelo pediatra como quase um natimorto, exceto por leve batimento cardíaco. O documentário exibe o feto nascido com deformidade. A enfermeira o traz embrulhado e pergunta se Tatielle quer ver: ela não reage. Já no enterro, a sogra, avó da criança, pede para ver o corpo. $\mathrm{O}$ agente funerário hesita em abrir o caixão. Abre apenas de um lado e pede que apenas ela veja. A sogra chora silenciosamente. A despeito do sofrimento denunciado, cenas de choro se restringem à sogra e à irmã de Tatielle.

O filme é construído em torno da figura de vítima da mulher impedida de realizar a interrupção de uma gestação de feto inviável, de seu sofrimento e de sua família, perplexa por não ter autonomia de atuação no caso. O Estado, na figura dos servidores dos dois hospitais públicos é um ator omisso, que lava as mãos para as dificuldades da gestante, em função do mandado judicial. Por fim, o padre que impediu o aborto para preservar a vida do nascituro é o personagem oculto que afeta toda a ação. Para o padre, o feto é sujeito de direitos. A família está convicta quanto à inviabilidade deste e quer fazer cessar o sofrimento, mas não encontra meios diante do habeas corpus. O documentário ilustra como os aparatos da Justiça acentuam o sofrimento, aspecto apontado por Víctora. (2011).

Horizontes Antropológicos, Porto Alegre, ano 20, n. 42, p. 293-325, jul./dez. 2014 


\section{Quem são elas?}

Quem são elas? (2006) é um documentário de Debora Diniz. Quando o Supremo Tribunal Federal cassou a liminar que permitia às mulheres grávidas de anencéfalo fazer a antecipação do parto, um dos ministros perguntou "Quem são elas? Falam tanto dessas mulheres, mas eu nunca as vi." Trazer a história dessas mulheres foi a inspiração para o documentário. Foram procurados serviços públicos de medicina fetal para contatar as mulheres que fizeram a antecipação de parto durante a vigência da liminar, perguntando se queriam contar suas histórias. Das 58 mulheres que responderam positivamente, quatro foram selecionadas para dar seu depoimento no filme. Érica, um caso de gravidez na adolescência; Dulcinéia, de 33 anos e mãe de sete filhos de pais diferentes; Camila, de 21 anos, que desejava o filho desde os 16 anos; e Michele, que fez tratamento de reprodução assistida para engravidar. As entrevistas ocorreram pouco tempo após a cassação da liminar, e dois anos depois foram realizadas novamente para mostrar uma etapa no ciclo da vida. A interrupção ocorreu em fases diferentes: de 16 a 24 semanas. As entrevistas aconteceram nas casas delas. Todas estavam acompanhadas por seus maridos na primeira entrevista, exceto por Dulcinéia que estava cercada pelos filhos.

As quatro externam seu choque ao descobrir que o feto era um anencéfalo. Dulcinéia relata que o "pai" achou que era mentira dela. Dulcinéia relata com mais dor a percepção de que o filho não iria sobreviver. Camila conta o medo de ser obrigada a levar a gravidez até o final. Ela saiu do hospital no dia em que foi noticiada a cassação da liminar. Michele chora ao contar que havia passado da incapacidade de dar filhos ao marido para uma gestação de uma criança tão desejada, mas que ela não aceitou, pois queria a filha perfeita. Érica relata que um crente no Hospital das Clínicas lhe disse que Deus faria crescer um cérebro e refuta essa ideia, pois ele teria que começar perfeito: o feto iria crescer, mas não mudar. Érica faz a afirmação mais forte no sentido da autonomia: "Eles não têm o direito de fazer isso com ninguém. De decidir a vida dos outros. A pessoa tem que ter o direito de escolher se ela quer levar isso adiante."

Camila relata ter sofrido depressão após o diagnóstico. Dulcinéia interpretou a princípio o fato como um castigo de Deus por seus pecados. As demais não usam linguagem religiosa, embora ostentem sinais de adesão religiosa: Érica veste uma camiseta com o dizer "Jesus Cristo mudou meu viver" e Camila tanto na primeira como na segunda entrevista é filmada com figuras 
religiosas ao fundo: uma imagem de N. Sra. Aparecida enfeitada por um terço, na segunda, uma Bíblia com um terço e duas imagens da santa.

Na segunda entrevista, Michele e Érica são mães. Camila se separou do marido e Dulcinéia está sozinha. Todas relatam se recordar da gestação anterior e pensar ou sonhar com o filho. As quatro afirmam ter feito a coisa certa, pois continuar com a gravidez sabendo que o filho morreria no nascimento seria apenas sofrer mais. Michele não sente culpa e admite ter saudade do filho. Érica diz que não adiantaria, porque o filho não estaria com ela hoje. Elas recusam esse sofrimento. Dulcinéia foi questionada por uma pessoa conhecida por ter "tirado". Ela respondeu que o outro não sabia o que ela estava sofrendo. Érica e Michele consideram que ter um filho logo depois as ajudou a superar o sofrimento. Camila relata o sentimento de alívio após a interrupção:

Eu estava sentindo falta. Eu estava sentindo saudade. Estava doendo, porque era o primeiro filho, mas foi a mesma coisa que tirar com a mão o que eu estava sentindo, o peso, que parecia que eu estava carregando o mundo dentro de mim. Não era um filho.

O filme constrói o relato das mulheres como testemunho de seu sofrimento com aquele tipo de gestação que não geraria uma criança viva e da autonomia destas em decidir. Na segunda entrevista, o filme mostra que todas avaliam positivamente sua decisão. O filme não mostra imagens dos anencéfalos, mas o foco está nas vítimas: as mulheres que aguardavam a decisão do STF e que não poderiam decidir enquanto isso.

\section{0 aborto dos outros}

O documentário O aborto dos outros (2008) foi dirigido por Carla Gallo e lançado em 2008. O roteiro segue algumas histórias dentro do Centro de Referência da Saúde da Mulher (CRSM) do Hospital Pérola Byington. O documentário não informa o nome dos entrevistados, exceto o de peritos. Os rostos da equipe médica sempre aparecem. $\mathrm{O}$ documentário segue a entrada de uma adolescente acompanhada da mãe que recorre ao serviço de aborto legal por ser vítima de estupro. O filme segue desde a entrevista inicial da adolescente com psicóloga até a saída do hospital. São cenas de entrevistas com psicólogas, medicação, sedação, centro cirúrgico e retorno ao quarto. Ambas 
expõem seu sofrimento. Essa narrativa é intercalada com outras mais curtas de quatro mulheres com casos bastante distintos. A primeira é uma mulher negra fazendo ultrassom obstétrico com o diagnóstico de feto portador de duas anomalias incompatíveis com a vida (acrania e doença multicística). Seu médico explica o método e a indução do parto. Ele ressalta que a mulher deve estar munida de dois laudos para obter a autorização judicial para o aborto. Ela e o marido desejavam uma criança, mas ele a convenceu a buscar o abortamento, porque o sofrimento seria maior se esperasse o parto. Uma mulher branca de rosto oculto relata sua experiência de aborto ilegal: engravidou chantageada pelo marido de quem tentava se separar. O método foi Cytotec por ser mais barato. Seu receio foi ser repreendida pelo médico. Não sente arrependimento. Diz que, se for pecado, Deus vai perdoá-la porque a criança foi concebida de uma maneira violenta, sem amor. Outra mulher oculta relata quatro abortos, sendo três com "mães de anjo" e um em clínica com anestesia. As práticas abortivas variam: curetagem, sonda, injeção de um líquido. Ela diz que não faria de novo, pois gostaria de ter os cinco filhos com ela, mas alega falta de condição de criar os filhos sozinha. Ela considera que vai ter o castigo de Deus, pois "aqui se faz, aqui se paga". O caso de mais impacto é a entrevista com mulher negra que foi presa por ter recorrido a aborto ilegal, tomando um medicamento. No hospital, ficou algemada na cama por uma semana, com policiais se revezando diariamente para vigiá-la. Saindo do hospital, ela fez o corpo de delito e ficou presa por uma semana na cela com "criminosos". Relata ter ficado surpresa pela prisão de alguém por aborto, surpresa também de outros na delegacia que lhe perguntaram o que fazia ali. Foi denunciada por uma pessoa amiga que já havia feito aborto. No final, são entrevistados especialistas, todos da área de saúde, exceto por um, do direito. Os especialistas apresentam posições favoráveis à legalização do aborto considerado problema de saúde pública: as mulheres pobres de Terceiro Mundo sofrem mais dano com a ilegalidade, a penalização sendo injusta e ineficaz, daí a importância do atendimento no sistema de saúde para redução de riscos.

\section{O fim do silêncio}

O documentário O fim do silêncio (2008), dirigido por Thereza Jessouroun, tem apoio da Fiocruz. O filme retrata mulheres brasileiras

Horizontes Antropológicos, Porto Alegre, ano 20, n. 42, p. 293-325, jul./dez. 2014 
que passaram por experiências de aborto clandestino. Apenas dois casos são exceção: uma que recebeu autorização para aborto em gestação de anencéfalo e outra que sofreu aborto espontâneo, mas foi tratada no serviço de saúde como se houvesse provocado. A identidade dessas mulheres é revelada, o que contrasta com o filme $O$ aborto dos outros, que oculta nomes e rosto muitas vezes.

O filme intercala entre os depoimentos quadros com dados sobre aborto. As depoentes são de grandes centros do Brasil e pertencem às camadas médias e às classes populares. Os depoimentos são coletados em suas casas.

Com respeito aos métodos, as mulheres de camadas médias optam por clínicas caras a fim de ter uma intervenção segura, mas também usam misoprostol. Uma tentou o misoprostol, porque uma amiga fizera aborto em clínica e relatou a dor da raspagem. Há relatos de uso errado do misoprostol e mal-estar ou mesmo da necessidade de internações: uma delas disse que o feto estava morto, em pedaços, mas não o expulsava, por isso foi internada para curetagem. Além do uso de chás, várias fizeram o aborto em "curiosas" ou em clínicas precárias, com relato de injeção de substância (iodo, sonda) para expulsar o feto depois em casa. Algumas foram internadas com infecção, outras receosas evitaram a internação, combatendo a infecção com antibióticos. Uma conta da retenção da placenta e ter forçado a expulsar em casa. Há o receio da denúncia à polícia, mas também do atendimento pela equipe médica com indagações se o aborto foi provocado. Uma depoente que começou a ter aborto espontâneo aos seis meses de gestação procurou o serviço e foi admoestada: "Mãe, não se faz aborto aos seis meses" - acusação de ter provocado. Nasceu um feto anencefálico, razão do aborto espontâneo. Outra relata maus tratos no serviço de saúde, após ter feito o aborto em uma clínica precária. Ela foi internada à noite e só atendida no dia seguinte e ouviu as atendentes dizerem: "Ela tentou aborto, deixa ela sofrer para sentir o que fez." Algumas defendem a legalidade do aborto, mas uma se disse favorável apenas em caso de anencefalia. Ela teve uma primeira gestação de anencéfalo e foi encaminhada por sua chefe para obter a autorização aos sete meses de gravidez. A empresa a apoiou para pagar o advogado. No momento da entrevista, estava grávida novamente com diagnóstico de anencefalia, mas resolveu continuar a gravidez na expectativa de que não fosse anencéfalo. O parto ocorreu duas semanas depois da entrevista, e o anencéfalo viveu por 12 horas. 
Quais as justificativas apontadas? Apenas uma depoente ressaltou não ter desejo de filhos, a gravidez ter sido decorrente de falha de contracepção. As de classe média estudantes do ensino médio ou superior alegaram não estar preparadas por serem muito jovens (16 e 19 anos) sem maturidade e sem um parceiro de confiança. Outras já tinham filhos e se disseram sem condições de ter mais um por questões financeiras, estando separadas quando descobriram a gravidez, ou contaram com o apoio do companheiro que assentia no aborto. Uma cristã disse ter sido obrigada pelo companheiro. Outras destacam a dificuldade para obter acesso no serviço público aos métodos contraceptivos e o impedimento de fazer laqueadura devido à idade mínima. Outras reclamam que o Estado cobra a continuidade da gestação, mas não oferece condições materiais e sociais para se criar o filho.

No tocante ao segredo, uma jovem temeu a reação de sua família então recentemente convertida para a religião evangélica e manteve segredo, embora fosse chantageada pelo namorado. Uma relata o apoio da mãe do namorado, uma mulher liberal, e o segredo em relação à sua própria família. Revelando um processo de decisão conflitivo, essa depoente jornalista diz: "um filho é um pedacinho de você. Não é uma coisa simples", comentando sua criação católica conservadora e a reação da mãe do namorado que lhe disse para "tirar esse mosquitinho logo", enquanto a médica que confirmou a gravidez a censurou por pretender abortar.

Nas entrevistas, em geral as mulheres não aparecem chorando ou se emocionando. Falam com segurança sobre as suas decisões com respeito às situações difíceis que viveram e como enfrentaram o sofrimento. Os relatos de negligência no atendimento e as acusações contra as mulheres que tiveram complicações e procuraram serviços de saúde revelam a violência que cerca o aborto clandestino. Só a que teve gestação de anencéfalo e foi orientada pela chefe se disse levada pelos outros. A que foi obrigada pelo marido não relata arrependimento: "Eu não sou a favor do aborto. Sou a favor da legalidade do aborto."

\section{Direito \& saúde: o caso de Alagoinha}

Direito \& saúde: o caso de Alagoinha (2010) é um documentário produzido pelo Ipas Brasil. Os documentários anteriores são centrados na esfera privada; em contraste, Direito \& saúde: o caso de Alagoinha aborda um evento

Horizontes Antropológicos, Porto Alegre, ano 20, n. 42, p. 293-325, jul./dez. 2014 
que virou notícia na imprensa brasileira e internacional. Em Alagoinha (PE), constatou-se que uma menina de 9 anos estava grávida de gêmeos em decorrência de relação sexual com o padrasto, caso imediatamente interpretado como estupro. A menina foi levada por sua mãe a um serviço de aborto legal em Recife, porém a direção do hospital recebeu um apelo do arcebispo de Olinda para não interromper a gravidez, de modo que a menina permaneceu no hospital para um pré-natal de alto risco. Por intervenção de duas ONGs feministas da região, Curumim e SOS Corpo, e da Secretaria Especial das Mulheres-PE, a menina é transferida para outro serviço de aborto legal, o Centro Integrado de Saúde Amaury de Medeiros (Cisam), ligado à Universidade de Pernambuco, e sofre a intervenção. Em depoimento para emissora de tevê, o arcebispo de Olinda declara que a mãe da menina, por ter autorizado o aborto, e a equipe médica, por ter realizado, incorreriam em excomunhão automática, mas haveria benevolência do direito canônico em relação à menina, por ser menor e não poder responder.

Também em contraste com os outros documentários, Direito \& saúde: o caso de Alagoinha é construído em parte significativa por imagens produzidas e veiculadas pela mídia: a detenção do acusado de estupro pela polícia e a entrevista com o arcebispo de Olinda, entre outros elementos, são reproduzidos de reportagens de uma emissora de Pernambuco, a TV Jornal (afiliada local do SBT), e de outras emissoras como Globo e Bandeirantes A mídia é um personagem: blogs e páginas da grande imprensa internacional são citados e comentados. Outra peculiaridade devida ao envolvimento de uma menina menor de idade é ausência de imagens da menina e de sua mãe, que são os principais atores do evento. Há depoimentos de pessoas que conheceram a família, destacando-se uma vizinha, a agente de saúde e o médico que diagnosticou a gravidez, uma representante do conselho tutelar. A ação do documentário se volta para a médica legista do IML de Recife, onde a menina é examinada novamente e são obtidos laudos, de onde a menina e sua mãe são encaminhadas para o Instituto Materno Infantil de Pernambuco (Imip). A médica legista fala na imprensa sobre o risco que a gravidez representava e da urgência em interrompê-la. A médica alertou que o serviço não havia encaminhado a menina para o aborto legal, mas para um pré-natal de alto risco. Paula Viana (da ONG Curumim) relata a presença de padre, pastor e do próprio Conselho Tutelar de Recife, interferindo para não haver interrupção da gravidez. O documentário mostra uma imagem do programa Canal Livre em que a afirmação 
da procuradora da Justiça LuizaNagib Eluf de que a menina corria risco de vida é questionada por Elizabeth Kipman (médica ginecologista): ${ }^{4}$

Dra. Elizabeth Kipman: É só porque ela tem 9 anos? Ela tinha 9 anos e ia dar à luz com dez. Eu já fiz parto de menina com dez. Na literatura...

Procuradora Luiza Nagib Eluf: Ela estava com gêmeos e poderia ter um problema de saúde grave.

Elizabeth: Isso foi usado politicamente.

Luiza: Mas você vai obrigar uma criatura de 9 anos a ser mãe?

Elizabeth: Isso é outra coisa.

Luiza: A ter uma gestação do próprio pai? Do padrasto?

Elizabeth: Você não disse que não sou eu que resolvo? Também não é você que resolve.

Luiza: Claro que não, mas também eu não fui dizer para ela fazer ou não fazer. A lei é que permite que ela faça.

Essa curta troca de frases mostra a dificuldade de diálogo entre militantes antiaborto e pessoas de posicionamento pró-escolha. Retrata a impossibilidade de ouvir outras razões que não as próprias. Em diversas situações de campo, verifiquei a ira mútua de ambos os lados. Muitos que advogam a posição pró-escolha acusam os antiaborto de fundamentalismo religioso. Por outro lado, os identificados militantes pró-vida são irredutíveis em sua lógica de defesa da vida do feto e do embrião em todas as circunstâncias sem conceder nenhuma razão a qualquer justificativa apontada.

$\mathrm{O}$ relato seguinte é o de um médico do Cisam descrevendo os riscos e assegurando que seriam maiores que uma gestação comum: pré-eclâmpsia, parto prematuro, ruptura de uma das bolsas, ruptura uterina. Após a mãe da menina ter sido informada da situação, enfoca-se a operação para tirar a menina do hospital, levar ao Cisam, com atuação de feministas do Curumim, do SOS Corpo e da Secretária de Políticas para a Mulher em Pernambuco e sua adjunta. Paula Viana aponta a atuação de enfermeiros e médicos pró-vida, chamados pejorativamente de pró-morte.

4 O programa não informou, mas Elizabeth Kipman Cerqueira integra a Comissão de Bioética da CNBB. Em minha investigação, constatei sua presença na audiência de instrução para a ADI 3510 no STF, sobre a pesquisa com células-tronco embrionárias, e na audiência pública para a ADPF 54 sobre antecipação de parto de anencéfalo.

Horizontes Antropológicos, Porto Alegre, ano 20, n. 42, p. 293-325, jul./dez. 2014 
O enfoque do documentário passa para o Cisam. Nenhum profissional do Imip depôs nesse documentário. Foram entrevistados do Cisam: recepcionista, assistente social, o técnico de enfermagem que atendeu, a diretora do Cisam, o diretor médico e diversos médicos. Vários comentários são feitos acerca do aborto como problema de saúde pública, do sofrimento das mulheres vítimas de violência sexual, sobre o Brasil ser um Estado laico, com crítica à interferência de religiosos nas políticas públicas. $\mathrm{O}$ documentário mostra a declaração do arcebispo de Olinda e Recife, D. José de Oliveira Sobrinho, que a excomunhão estaria mantida, mas que, em caso de arrependimento, o pecado teria perdão. A reação dos profissionais do Cisam é de reafirmar a correção do serviço prestado. Um médico afirma continuar sendo cristão e católico, caracteriza o atendimento dentro dos princípios cristãos de amor, compreensão e responsabilidade em exercer dignamente os seus papéis profissionais. Ele diz considerar que eles foram mais cristãos do que pessoas que se colocam em nome da Igreja, mas não tiveram o sentimento de amor pela criança. Edições online de diversos jornais do mundo trazem reações à declaração do arcebispo e o documentário registra a discordância de teólogos católicos e do Vaticano quanto à posição do arcebispo.

\section{Filmes e audiovisual antiaborto}

Os filmes antiaborto geralmente são centrados no feto. Aportes teóricos sobre a condição fetal são fundamentais para analisar aqui a construção de fetos e embriões como personagem e vítimas, o que será baseado em categorias formuladas pelo sociólogo Luc Boltanski (2004). Sintetizo aqui parte da classificação. $\mathrm{O}$ arranjo parental permite engendramento com características opostas: o feto autêntico caracteriza-se por sua antecipação, já reconhecido com uma pessoa e destinado ao futuro, enquanto o feto tumoral, aquele que não se integra ao projeto parental, é atirado ao nada de onde mal saiu. Os meios tecnológicos como as técnicas de reprodução assistida e os dispositivos jurídicos orientados à defesa do filho por projeto criam novas categorias, quando se estabelecem direitos do feto dentro do útero, ou se propõem cirurgias fetais. Define-se a categoria de tecnofeto a partir desse desenvolvimento tecnológico, exemplificado na formação de embriões congelados restantes da fertilização in vitro. A tentativa de esboçar um estatuto legal a partir da atribuição 
de dignidade ao embrião fora do corpo levanta a questão das fronteiras da humanidade. $\mathrm{O}$ tecnofeto desestabiliza a distinção nítida entre o feto autêntico e o feto tumoral. A visualização dos fetos também coloca em risco a distinção entre feto autêntico e feto tumoral, nos exemplos do uso de fotografias de fetos usadas pelos grupos antiaborto e das tecnologias de imagem que o mostram no útero. As tecnologias que tornaram o feto acessível aos sentidos e os conflitos envolvendo o feto permitiram sua entrada na sociedade. $\mathrm{O}$ acesso do feto ao mundo social se contrapõe à necessidade de fazê-lo desaparecer com a legalização do aborto. Abordagens desconstrucionistas vão contestar a crença na existência de um feto em si dotado de atributos permanentes e o mostram como um ser histórico e social. A figura do feto como ser humano essencial será retratada na produção audiovisual antiaborto.

\section{O grito silencioso (The silent scream)}

Bernarld Nathanson apresenta e narra o filme (The silent scream, 1984). Ele se apresenta como médico que realizou milhares de abortos e participou de uma liga para a liberação do aborto. Quando estudou medicina em 1949 não se falava do feto. Descreve o surgimento da ciência da fetologia na década de 1970, e sua dependência de inovações tecnológicas: como ultrassonografia, exame do coração. A filmagem de um feto sendo retirado em um procedimento de aborto, abrindo a boca e emitindo "um grito silencioso" o fez mudar de ideia, arrepender-se e apoiar os movimentos contrários à legalização.

Nathanson mostra a imagem de ultrassonografia e descreve o procedimento. Pela primeira vez é possível ver um aborto do ponto de vista da vítima: como uma criança vai sendo desmembrada, desarticulada pelos instrumentos do aborteiro. Mostra modelos tridimensionais de "crianças" desde as 4 semanas até 24 semanas. Essa "criança" já tem ondas cerebrais desde as 6 semanas. $\mathrm{O}$ feto pode ter tratado como o segundo cliente. A ética médica diz que não devemos destruir os clientes.

Ele explica o aborto através dos modelos e descreve cada instrumento usado. Mostra imagem ultrassonográfica de abortamento às 12 semanas: o médico explica a imagem e descreve as estruturas corporais. Ele diz que a criança se move para se afastar da ponta de sucção. Primeiro se fura o saco. Depois a ponta de sucção busca o corpo da criança. A criança está de boca 
aberta a "emitir um grito silencioso". Segundo Nathanson, o batimento cardíaco se acelera, o que provaria que a "criança" sente o processo. A cabeça é agarrada pela pinça e puxada para fora. $\mathrm{O}$ que sobra são resíduos, fragmentos que documentam que "ali viveu um indefeso ser humano".

O médico argumenta que antes da decisão Roe vs. Wade ${ }^{5}$ eram realizados cem mil abortos legais por ano e poucos ilegais. No primeiro ano após a decisão, surge uma indústria que atinge 700 mil abortos. São mostradas imagens de fetos e restos de ossos. Afirma que as mulheres são vítimas tanto quanto as crianças, pois não mostraram a elas a verdadeira natureza da criança. Retorna à ciência da fetologia como prova de que o feto pertence à humanidade. $\mathrm{O}$ aborto é um problema social. Sua solução é amor, compaixão e respeito pela prioridade da vida humana. Conclama a parar o genocídio. As imagens ultrassonográficas constituem o tecnofeto. Como o documentário mostra uma cena de aborto, trata-se de um tecnofeto que se torna vítima também. O documentário esforça-se para demonstrar que um feto de três meses passa por sofrimento físico e tenta se defender. Os fetos destroçados e seus restos correspondem à estética do grotesco (cf. Bakhtin, 1999). Ondas cerebrais indicariam a existência de um sujeito racional nos moldes da concepção de pessoa como indivíduo (Dumont, 1997).

\section{A dura realidade (Hard truth)}

A abertura do filme (Hard truth, 1991) mostra imagem de instrumentos cirúrgicos. O locutor do Center for Bioethical Reform fala das imagens: "bebês" entre 8 e 12 semanas recolhidos em lixeira de clínica de aborto de Houston. Já tem ondas cerebrais desde 6 semanas e coração completamente formado. Diz que o aborto por conveniência é permitido nos EUA durante os nove meses. Menciona a repressão ao ativismo antiaborto. Justifica a produção de imagens conforme às do Holocausto, para se reagir contra. Suprime-se a narração para o espectador se centrar nas imagens. São imagens do desenvolvimento desde as primeiras células. Ouve-se uma música de fundo: "O mais sublime que Deus pode nos dar é nossa própria vida, presente

5 Julgamento da Suprema Corte que liberou o aborto voluntário em todos os estados dos EUA no primeiro trimestre de gestação.

Horizontes Antropológicos, Porto Alegre, ano 20, n. 42, p. 293-325, jul./dez. 2014 
de quem sabe amar. A vida é um valor maior, reflexo de Deus que é fecundidade. Fonte do mais perfeito amor. Um verdadeiro milagre..." Sucedem-se imagens do desenvolvimento fetal dentro do saco gestacional. As imagens de uma intervenção para o abortamento só começam aos 4 min. Uma pinça puxa estruturas, depois uma cabeça. Uma cabeça enegrecida é manuseada. Depois um encéfalo com um olho. Há várias imagens de fragmentos identificáveis: pedaços do rosto, e dos membros com mãos e pés. Depois vem uma imagem de um feto com cabelo em estágio bem mais adiantado, inteiro dentro de uma bacia. Exibem-se imagens de manifestação antiaborto: um feto abortado sobre a bandeira dos EUA. Alternam-se imagens de partes de fetos com a polícia chegando a uma manifestação e arrastando ativistas, ou espancando com cassetete. Há muitas imagens de rostos e cabeças dilaceradas. Destacase a composição de fragmentos com cabeça, tronco, e braços abertos na forma de cruz sobre pano branco. Surgem imagens de fetos maiores e inteiros, alguns dos quais acinzentados, de pedaços de fetos destroçados mantidos em formol, bem como de fragmentos fetais sanguinolentos. O grito silencioso e A dura realidade têm propostas semelhantes, sendo que o último atualiza a proposta do mais antigo com belas imagens recentes da categoria tecnofeto. Tanto os fetos são tratados como vítimas dos autores dos procedimentos médicos como os militantes antiaborto são vitimados pela polícia, construindo uma áurea de heroísmo em torno deles. O grotesco (cf. Bakhtin, 1999) é mais estetizado quando se criam composições a partir dos restos embrionários na forma de cruz, que aponta a correlação: feto como vítima inocente crucificada como o foi Jesus.

\section{Flores de Marcela}

O documentário Flor de Marcela (2009) é exceção na perspectiva pró-vida, porque há um bebê, em vez de fetos ou embriões e por ser centrado na experiência da família. O filme é construído a partir da relação de Marcela de Jesus, anencéfalo de sobrevida excepcional, com sua família, e explica a anomalia com base no depoimento dos médicos que diagnosticaram e a atenderam. O médico fez o diagnóstico de anencefalia, confirmado por outro exame posterior e por um colega, e encaminhou a gestante para pré-natal de alto risco, sendo contrário ao aborto. Médica diz que é um caso clássico 
de anencefalia, porque faltam as estruturas do córtex cerebral: anomalia que ocorre em um a cada mil nascimentos, e alerta para a sobrevida excepcional, quando o prognóstico seria de 3 a 7 dias. Pai e mãe de Marcela rejeitaram sugestões de interromper a gravidez. Médica relata que Marcela ficou bem após o quarto mês, então no sexto mês a equipe médica propôs à família dar alta, desde que ela ficasse em um lugar perto do hospital com a estrutura adequada: um capacete concentrador de oxigênio para ela respirar. Os relatos representam a vida de relação: segundo a médica, Marcela se assusta com barulho de telefone e reconhece a voz da mãe, pois tem o conduto auditivo perfeito, mas não entende por não ter córtex onde processar os dados. A coluna dela é perfeita, então ela tem sensação de dor e de calor. A mãe relata que ela sorri, grita, se mexe se colocada em posição incômoda, e sente, pois cospe alimentos que não aprecia. Poucas imagens mostram a cabeça de Marcela descoberta, com as estruturas do encéfalo à mostra, em quase todas, ela está de gorro. Há uma sequência de depoimentos da família sobre a relação com Marcela. Mãe de Marcela fala de seu amor pela filha: "Marcela é especial, porque não iria viver nem quinze segundos." A irmã diz: "Marcela é um anjinho que veio para nos iluminar. Ela vai continuar salvando a vida de muitas crianças." O pai apela: "Aos pais, eu quero dizer que não eliminem seus filhos, porque depois o sofrimento vai ser muito maior, porque você vai matar uma criança sem defesa." A mãe conta: "A gente comemora o aniversário dela a cada mês. Ela completou 1 ano e 2 meses." A mãe considera ter cumprido uma missão: "Eu fiz a vontade de Deus. Eu deixei nascer." A música de fundo final é: "O som do teu amor me faz canção. Lança suave luz em mim, em nós". A família de Marcela é retratada como exemplo de superação religiosa do sofrimento e de aceitação do bebê anencefálico. As limitações na vida de relação de Marcela, critério para reconhecer existência de vida humana, são minimizadas, ${ }^{6}$ exceção feita ao filme, que tenta mostrar o vinculo da família ao bebê anencefálico, mas também a capacidade relacional da menina, um dos atributos para reconhecer a presença de vida humana (Penna, 2005).

\footnotetext{
6 Penna (2005) em artigo comparando anencefalia e morte neurológica afirma o caráter de natimorto do anencéfalo a partir de sua impossibilidade de ter consciência e sensibilidade, em função da ausência do córtex cerebral. A partir da consciência e sensibilidade se forma a vida de relação.
} 


\section{Deixe-me nascer (slide show)}

A "palestra em defesa da vida" é a produção mais didática de todas, que explicita em 80 lâminas os objetivos de seus criadores: o Movimento em Defesa da Vida da Arquidiocese do Rio de Janeiro. O primeiro slide traz o título "Deixe-me nascer!" e mostra um "bebê com 7 semanas". Os slides 2 a 10 lançam uma série de questionamentos e suas respostas. Do 2 ao 5, a pergunta é "quando começa a vida humana?" A primeira resposta é: na fecundação (imagem de microscopia), afirmando que qualquer método para destruição dessa vida é assassinato. Do 6 ao 10, as perguntas se referem ao estatuto do feto referido como bebê no ventre materno: se é um ser humano; se é parte do corpo da sua mãe, com a resposta de que é outra pessoa porque é dotado de "código genético próprio" "que lhe confere uma identidade única"; se tem direito à vida, direito considerado inalienável; e se precisa de proteção. O último slide cita um salmo. ${ }^{7}$

Da lâmina 12 a 30, há uma sequência de "fotos reais do desenvolvimento do bebê no ventre materno, em várias fases da gestação" obtidas com permissão de Padres pela Vida, dos EUA (www.priestsforlife.org). São imagens de fetos designadas de bebês a partir de 7 semanas de gestação até seis meses. As fotos são claras e límpidas, e enfocam ora o corpo inteiro de frente ou de perfil, ora são closes de partes do corpo: rosto, em particular a boca, cabeça orelhas, mãos, pernas, pés, às vezes com detalhes das unhas, cordão, em geral conjugando esses elementos conforme a posição. Os fetos parecem flutuar no vazio. Inicia-se outra série com o slide 31 intitulado "Aborto. O pior de todos os ataques contra a vida humana" com enfoque no "abortamento PROVOCADO". Os slides 33 a 37 são uma sequência de perguntas e suas respostas com uma gradação que diz respeito aos tipos de aborto permitidos na legislação brasileira, e os argumentos em defesa da descriminalização do aborto: risco de vida da mãe, estupro, redução da mortalidade materna, consequências físicas e psíquicas do aborto provocado. A pergunta se o aborto deveria ser descriminalizado tem a resposta: "um crime" "deve ser combatido, nunca 'transformado' em direito".

\footnotetext{
"Fostes vós que plasmastes as entranhas de meu corpo, vós me tecestes no seio de minha mãe. Seja bendito por me haverdes feito de modo tão maravilhoso. Pelas vossas obras tão extraordinárias, conheceis até o fundo a minha alma." (Salmo 138,13-14 na numeração católica e Salmo 139 na numeração da Bíblia versão protestante.)
} 
Repete-se o argumento que o aborto implicaria mais riscos que a gestação. Destaco a resposta do slide referente a estupro: afirma que não vai apagar o trauma da violência sexual, e que a mulher deve receber apoio psicológico da família, amigos e do Estado, pedindo proteção para o "bebê" e punição para o estuprador. Uma pintura de Nossa Senhora das Dores ilustra a sequência. As duas primeiras sequências de lâminas representam o surgimento do tecnofeto como decorrência de meios tecnológicos e de dispositivos jurídicos: além das tecnologias de imagem microscópica e fetal que dão acesso ao ente, a legislação cria esses seres como sujeitos, como na argumentação contrária ao aborto provocado que considera a destruição de vida humana um assassinato.

A nova série adverte para o teor das "fotos reais de bebês abortados", cujos corpos ou partes foram encontrados no lixo de "clínicas" de aborto nos Estados Unidos, país onde é legalizado desde 1972 (sic), obtidas com permissão do Center for Bio-Ethical Reform. Os slides 39 a 49 mostram imagens sanguinolentas de fragmentos de embriões ou fetos a partir de 8 até 11 semanas, em seguida de fetos inteiros no segundo trimestre de gestação, esses últimos pálidos ou enegrecidos, com designação "aborto de bebê" seguido do período de desenvolvimento. As fotos dos fragmentos mostram rostos, pedaços de cabeças, mãos, braços, pés e pernas, algumas construídas, ao remontar cabeça, tronco e membros dos destroços sobre mãos com luvas descartáveis, ou compondo imagens de mãos e pés sobre moedas de dólar. O contraste com mãos de adultos ou com moedas sugere o tamanho reduzido dos embriões abortados. Em três fotos, os fetos inteiros mais desenvolvidos são apontados por mãos. A cor enegrecida sugere sua conservação em formol. A construção dessas imagens é um contraponto às dos fetos em desenvolvimento, não apenas por apontarem mortes e destruição, mas pelo isolamento dos primeiros. As fotos do desenvolvimento fetal sugerem um ente livre flutuante (cf. Salem, 1997 e Strathern, 1992), como indivíduos que não dependessem de estruturas corporais maternas para subsistir, enquanto o laço social está explicitado nas mãos que mostram os fragmentos ou fetos abortados, bem como o ícone financeiro da acusada indústria representado pela moeda americana sobre a qual os destroços são arrumados. Constrói-se mais uma vez a imagem no estilo grotesco, com ênfase na monstruosidade dos fragmentos. Através desse contraste entre as belas imagens do tecnofeto desconectado e fora de contexto e dos fragmentos fetais se constitui a imagem de vítima, necessária para o apelo emocional e político desse discurso. 
Os slides 50 a 52 fazem o contraponto religioso por meio de pinturas de passagens bíblicas: ${ }^{8}$ o massacre dos inocentes, a fuga para o Egito, e de "Cristo e a criança".

A partir do slide 53 até o 74, há textos informativos, denunciando "estratégias abortistas" nos Estados Unidos e no Brasil, acusadas de distorção de dados, depois mostrando a legislação brasileira e internacional da qual o Estado brasileiro é signatário, e as questões legislativas mais recentes como o debate sobre a lei $n^{\circ} 11.105 / 2005$, a Lei de Biossegurança (Brasil, 2005), e o "monitoramento político" da tramitação dos projetos para legalização do aborto no Brasil e o Estatuto do Nascituro. Destaca-se a inviolabilidade do direito à vida garantida pela Constituição (artigo $5^{\circ}$ do capítulo I). A partir do artigo 128 do Código Penal, os dois casos em que não se pune o aborto, afirmam que este "continua sendo juridicamente considerado crime" e "portanto, o aborto é ilegal no Brasil". Eis novamente o dispositivo jurídico construindo o tecnofeto.

Os slides 60 a 66 discutem a Lei de Biossegurança com respeito à pesquisa com células-tronco embrionárias no Brasil e a rejeitam assim como recusam a produção de embriões para reprodução assistida.

No bloco de monitoramento político, discute-se o substitutivo do projeto de lei $\mathrm{n}^{\circ}$ 1.135/1991 (Brasil, 1991) que pretende descriminalizar o aborto e garantir sua oferta pelo Poder Público. Também se apresenta o projeto de lei $n^{\circ} 478 / 2007$, Estatuto do Nascituro (Brasil, 2007), que "protege a vida humana desde o momento da concepção" e propõe que o Estado pague pensão à mãe e ao bebê gerado em estupro. ${ }^{9} \mathrm{O}$ último slide refere-se ao Supremo Tribunal Federal e a anencefalia, e rejeita a ADPF 54 que pleiteia a antecipação terapêutica do parto.

$\mathrm{O}$ encerramento da palestra retoma a linguagem religiosa. O slide "O que é a legalização do aborto?" resume a palestra. Define o aborto sob diversos pontos de vista: jurídico: nega o direito do bebê à vida; médico: mata o bebê e prejudica a mulher; ético: discrimina seres humanos; social: desumaniza a sociedade; religioso: desconsidera a dignidade sobrenatural do ser humano; factual: não diminui a mortalidade materna. A ilustração é a pintura de Nossa

8 A fonte das pinturas de Matteo e Bloch é http://freechristimages.org. A fonte de todas as imagens de Maria é http://www.marysrosaries.com.

9 Essa prática de assistência para manter a gestação decorrente de violência sexual é acusada pelas feministas de ser uma bolsa estupro. 
Senhora das Dores. O slides seguintes conclamam à ação para salvar bebês do aborto e pedem para rezar para livrar o Brasil do crime de aborto e em favor da defesa da vida. A projeção se encerra com o rosto de feto em gestação.

\section{Consideracõos finais}

O presente artigo examinou filmes sobre a temática do aborto de orientação pró-vida e pró-escolha na tentativa de apreender a profusão de imagens veiculadas na movimentação antiaborto, e de verificar a resposta entre os que lutam pela legalização. $\mathrm{O}$ exame não se deteve nas imagens visuais, mas se estendeu às narrativas faladas ou escritas presentes nos filmes. Optou-se por considerar apenas o formato de documentário. Pollak (1989) afirma a importância do filme como suporte para captar lembranças em objetos de memória, ressaltando o papel dos gêneros filme-testemunho e do documentário como instrumentos para rearranjo da memória coletiva. Se a análise do discurso é parte da rotina antropológica, a análise de filmes e de sua construção como artefatos visuais impõe um desafio distinto. Importa considerar a natureza desse tipo de imagem: "Imagens, especificamente as que resultam das modernas técnicas de reprodução, como as fílmicas ou fotográficas, são signos que pretendem completa identidade com a coisa representada, como se não fossem signos.” (Novaes, 2008, p. 456). Imagens fílmicas e fotográficas escondem os mecanismos de representação de que resultam e iludem ao parecerem naturais e transparentes, continua Novaes, mas são eficientes na comunicação simbólica. Este artigo pretendeu investigar a eloquência de imagens veiculadas no debate público acerca do aborto. Bazin (1991 apud Novaes, 2008, p. 462) atribui o poder de credibilidade da fotografia ao seguinte aspecto: "A fotografia se beneficia de uma transferência de realidade da coisa para sua reprodução."

A seleção abrangeu desde filmes premiados em festivais de cinema, como Uma história Severina, de um lado, até a estética do grotesco nos documentários pró-vida que pretendem uma representação realista do aborto sem mediações. $O$ grito silencioso (Silent scream) é o clássico filme antiaborto realizado em 1984. O filme A dura realidade (Hard truth) foi gravado nos Estados Unidos, onde o aborto é legalizado. Um sinal dos momentos distintos da produção desses filmes foi a presença de registro de piquetes em frente às clínicas de aborto no último. As imagens dos fetos foram obtidas de organizações internacionais. 
Seriam restos coletados em lixeiras de clínicas de aborto, conforme a explicação dada nos filmes, mas diversas fotos dispõem dos restos com certo arranjo. A produção brasileira Flores de Marcela é de 2009. O filme retrata Marcela com 1 ano e 2 meses (ela viveu até 1 ano e 8 meses). O slide show "Deixe-me nascer" para palestras foi atualizado no início de 2012.

Já os filmes pró-escolha sob análise foram finalizados entre 2005 e 2009 no Brasil, o que indica um esforço recente de debater o problema do aborto por parte de feministas. Só há diretoras mulheres, exceto por Ramon Navarro, que divide roteiro e direção com Debora Diniz em Habeas corpus (2005).

A análise do material de ambos os lados sugere uma conexão entre a defesa da condição de pessoa como indivíduo (cf. Dumont, 1997) e a atribuição do estatuto de vítima. $\mathrm{O}$ exame desse material permite pensar a extensão que essa figura adquire na sociedade contemporânea como forma de legitimação moral de demandas sociais (Sarti, 2011, p. 51). Como na observação de Marilena Chauí quanto ao debate sobre mulher e violência citada por Sarti (2011, p. 53), "desaparecem as figuras da ambiguidade", os filmes pró-escolha constroem uma identidade unicamente positiva das mulheres que fazem aborto, e o lado pró-vida, a imagem dos fetos, reportados como crianças não nascidas, ou anencéfalos, todos vítimas inocentes. Conforme observado por Sarti, este trabalho enfoca também de que modo a sociedade administra conflitos na contemporaneidade. Os filmes representam que significados a noção de vítima adquire nos diferentes contextos. Segundo Sarti (2011, p. 54), "a construção da pessoa como vítima no mundo contemporâneo é pensada como uma forma de conferir reconhecimento social ao sofrimento". Sarti comenta sobre o impacto de movimentos sociais de cunho identitário nas esferas do direito e da saúde que se articulam no processo de produção da vítima. Retomo aqui a denúncia da criminalidade da regra e da ordem social analisada por Das (2011). O Estado surge como agente que agrava o sofrimento das mulheres cuja opção é fazer o abortamento em contexto de ilegalidade. Também há a violência de ter que esperar a autorização judicial a fim de pôr termo a uma gravidez de feto inviável e abreviar o sofrimento da gestante. Os documentários relatam o que foi resguardado na esfera do indizível e ocorre na clandestinidade, ou mesmo aquilo que quando autorizado legalmente é ocultado. De forma semelhante, a tentativa do movimento antiaborto é demonstrar o sofrimento dos fetos abortados e atestar sensibilidade e vida de relação nos anencéfalos: acedendo ao estatuto de vítima é possível conquistar a posição de sujeito. 
Acompanhando etnograficamente o debate público sobre o aborto inseguro, no qual os presentes filmes pró-escolha analisados são parte integrante, observam-se estratégias de convencimento da sociedade e do Estado, de mostrar quantas mulheres morrem ou sofrem sequelas pelo aborto clandestino, ou seja, são vítimas em busca de socorro. No presente trabalho, considerando essa lógica, ambos os lados pró-escolha e pró-vida buscam alcançar o reconhecimento social do sofrimento de mulheres e de fetos. O problema é que ao construir a condição de vítima de um, nega-se a condição de vítima do outro. O feto seria vítima da gestante representada como assassina egoísta que não o deixa viver quando opta pelo aborto. No discurso pró-vida, produz-se uma hierarquização, no sentido de Dumont (1997), em que o feto engloba a mulher, seu suporte. Simetricamente, o discurso pró-escolha parece negar a existência do feto, ou seu sofrimento, posto que o aborto voluntário é realizado no início da gestação, e o feto não teria sensibilidade nervosa, ou no caso de anencefalia e outras anomalias incompatíveis com a vida, ou malformações graves, o feto seria inviável. Conforme o englobamento hierárquico, a mulher é reduzida de sua condição de sujeito pleno, uma vez que a personalidade civil só se dá com o nascimento com vida, a um aparelho de suporte de um ente em desenvolvimento, construído como sujeito de direitos pelo discurso antiaborto.

$\mathrm{Na}$ gravidez indesejada, o feto é um problema na vida da mulher. Tratase da figura do feto tumoral, categoria criada por Boltanski (2004) para se referir ao feto que não integra um projeto parental. Quando os filmes e a projeção para palestra atribuem a condição de vítimas e de sujeitos indefesos aos fetos sob risco de intervenção para abortamento, é contestada a representação destes como objeto, ou material a descartar. O filme Flores de Marcela mostra a menina com diagnóstico de anencefalia como vítima potencial daqueles que pretendiam matá-la com a interrupção da gravidez. A projeção de slides para a palestra "Deixe-me nascer" qualifica o feto anencefálico como o mais indefeso dos entes, que merece a proteção da sociedade.

No caso das mulheres que fazem abortamento voluntário, os filmes pró-escolha demonstram sua condição de sujeitos de direito; assim, o direito ao aborto é apresentado como sinal de autonomia feminina. Contudo, no contexto brasileiro, o argumento da autonomia feminina tem pouco peso político, o que se revelou na retirada dessa expressão do $3^{\circ}$ Programa Nacional de Direitos Humanos (PNDH3) e da proposta de enviar ao Congresso Nacional projetos 
pela descriminalização do aborto (Luna, 2014). Vários filmes constroem a mulher como vítima do aborto ilegal e inseguro, enquanto nos exemplos de anencefalia e outras anomalias incompatíveis com a vida, a mulher seria vítima da legislação restritiva que a impede de interromper a gravidez de um feto inviável, prolongando o sofrimento da gestante e de sua família. O poder dessa burocracia do Estado insensível ao sofrimento das mulheres é revelado no esforço de Severina e seu marido para obter a autorização e antecipar o parto, conforme retratado em Uma história Severina. No documentário Habeas corpus, isso fica explícito ainda mais na atuação intolerante do padre Lodi que impetrou o habeas corpus em favor do feto, impedindo Tatielle e sua família de obter a interrupção da gravidez, o que prolongou seu sofrimento, exemplificando as tramas burocráticas que acentuam o sofrimento (cf. Víctora, 2011). O filme é construído para sugerir uma exibição de sofrimento sem sentido, principalmente por parte da gestante, mas também de sua família, que demonstra a inconformidade.

Conforme explicitou Boltanski (2004) em La condition foetale, o uso da imagem é um dos aspectos cruciais na construção do tecnofeto, categoria com grande potencial essencializador. Partindo do texto de Novaes (2008) sobre antropologia visual, o presente exercício de análise levanta a pergunta de quando a imagem tem ou não caráter acessório no material analisado. $\mathrm{O}$ uso de imagem parece mais crucial na narrativa pró-vida, que chega a dispensar a narração com palavras em trechos do filme A dura realidade, enquanto a abordagem pró-escolha é mais centrada na narrativa dos sujeitos: as mulheres. Já na perspectiva pró-vida o sujeito feto vítima de violência é a narrativa.

Muitos trabalhos recentes acerca da violência sugerem que, quando se se contempla a violência, atinge-se uma espécie de limite da capacidade de representar. Em geral apresentados sob o signo do "horror", eles nos fazem pensar como seres humanos podem ter sido capazes de atos tão hediondos, em tão grande escala [...]. Parece que entendemos tais atos como chocantes e inimagináveis apenas quando temos uma idéia formada acerca de como o ser humano deva ser construído. Essas descrições servem, assim, para reafirmar as fronteiras entre civilizado e selvagem, e também permitem que nossa imagem do sujeito humano permaneça intacta. (Das, 1999, p. 31).

Essa crítica de Veena Das acerca de determinadas representações da violência cabe à construção de imagens pela produção audiovisual pró-vida,

Horizontes Antropológicos, Porto Alegre, ano 20, n. 42, p. 293-325, jul./dez. 2014 
que pretende chocar e opor os "selvagens" que praticam aborto aos "civilizados" que condenam tal prática. No intuito de formalizar a denúncia do aborto como uma prática do mal em termos absolutos, os documentários e slides pró-vida recorrem a imagens ditas realistas dos restos mortais de fetos inteiros ou de embriões despedaçados. Em observação etnográfica de protestos contra o aborto, verificou-se que várias dessas imagens eram justapostas às obtidas no Holocausto realizado pelos nazistas durante a Segunda Guerra. Ao buscar a força da imagem em si, os autores desses filmes acabam por produzir uma estética do grotesco, em que pinças revolvem restos para buscar pedaços de mãos, olhos e rostos de indivíduos destroçados. Remete-se aqui à análise de Bakhtin (1999) sobre a estética do grotesco. Na construção desses filmes, é necessário antes mostrar as imagens límpidas e clássicas do tecnofeto, conforme a categoria de Boltanski (2004), para obter por contraste a reação de horror a partir das imagens grotescas de restos sanguinolentos, como em uma batalha. Outra figura que pode ser associada ao grotesco é a do anencéfalo, ou outros fetos portadores de anomalias incompatíveis com a vida, em geral apresentando deformidades. Enquanto os destroços de embriões são apresentados nos documentários pró-vida de forma a escandalizar, a apresentação do anencéfalo tanto nos documentários pró-vida como nos pró-escolha é mais respeitosa. $\mathrm{O}$ esforço do diretor de Flores de Marcela é mostrá-la como o anjinho que sua família descreve, e produzir essa imagem de fragilidade inocente, embora seja óbvia a deformidade na cabeça, mesmo quando vestida com a touca. Já em Habeas corpus e em Uma história Severina, os anencéfalos mortos são respeitosamente mostrados envolvidos em lençol, e em História Severina inclusive na foto em que o bebê está vestido com a roupinha do enterro. O exemplo do anencéfalo remete à análise de Foucault (2002, p. 69) sobre os anormais, especificamente na figura do monstro humano, "que constitui em sua existência mesma e em sua forma, não apenas uma violação das leis da sociedade, mas uma violação das leis da natureza", de modo que seu campo de aparecimento é um domínio jurídico-biológico. O debate se o anencéfalo é uma forma de vida humana, ou se tem viabilidade fora do útero materno se inscreve nesse domínio jurídico-biológico sobre o qual os filmes duelam. Mostrar a experiência da gestante que, tendo obtido uma autorização judicial para interromper a gravidez de um feto portador de anomalia incompatível com a vida, por força de um habeas corpus é obrigada a levar a termo a gravidez, ou mostrar o milagre biológico da sobrevida de uma menina 
com o diagnóstico de anencefalia para forçar o convencimento legal da proteção de todos os fetos malformados, frágeis e indefesos: ambos os lados estão inscritos nesse domínio jurídico-biológico.

\section{Referências}

O ABORTO DOS OUTROS. Direção: Carla Gallo. Produção: Paulo Sacramento. São Paulo: Olhos de Cão, 2008. 35 mm (72 min).

BAKHTIN, M. A cultura popular na Idade Média e no Renascimento: o contexto de François Rabelais. 4. ed. São Paulo: Hucitec; Brasília: EdUnb, 1999.

BOLTANSKI, L. La condition foetale: une sociologie de l'engendrement et de l'avortement. Paris: Gallimard, 2004.

BOLTANSKI, L. As dimensões antropológicas do aborto. Revista Brasileira de Ciência Política, n. 7, p. 205-245, 2012.

BOURDIEU, P. O poder simbólico. Rio de Janeiro: Bertrand Brasil, 1998.

BRASIL. Câmara dos Deputados. Projeto de lei no 1.135, de 1991. Suprime o Art. 124 do Código Penal Brasileiro. Diário do Congresso Nacional, Brasília, 18 jun. 1991. Seção I, p. 9771. Disponível em: <http://imagem.camara.gov. br/Imagem/d/pdf/DCD18JUN1991.pdf\#page=25> . Acesso em: 30 dez. 2013.

BRASIL. Lei $n^{\circ}$ 11.105, de 24 de março de 2005. Regulamenta os incisos II, IV e V do $\S 1$ o do art. 225 da Constituição Federal, estabelece normas de segurança e mecanismos de fiscalização de atividades que envolvam organismos geneticamente modificados - OGM e seus derivados, cria o Conselho Nacional de Biossegurança-CNBS, reestrutura a Comissão Técnica Nacional de Biossegurança - CTNBio, dispõe sobre a Política Nacional de Biossegurança - PNB, revoga a Lei no 8.974, de 5 de janeiro de 1995, e a Medida Provisória no 2.191-9, de 23 de agosto de 2001, e os arts. 5 $5^{\circ}$, $7^{\circ}, 8^{\circ}, 9^{\circ}, 10$ e 16 da Lei $n^{\circ} 10.814$, de 15 de dezembro de 2003 , e dá outras providências. Brasília, 2005. Disponível em: <http://www.planalto.gov.br/ ccivil_03/_ato2004-2006/2005/lei/111105.htm>. Acesso em: 30 dez. 2013. 
BRASIL. Câmara dos Deputados. Projeto de lei $n^{\circ} 478$, de 2007. Dispõe sobre o Estatuto do Nascituro e dá outras providências. Brasília, 2007. Disponível em: <http://www.camara.gov.br/proposicoesWeb/prop_mostrarintegra?codte or $=443584 \&$ filename $=P L+478 / 2007>$. Acesso em: $30 \mathrm{dez} .2013$.

DAS, V. Fronteira, violência e o trabalho do tempo: alguns temas wittgensteinianos. Revista Brasileira de Ciências Sociais, v. 14, n. 40, p. 3142, 1999.

DAS, V. O ato de testemunhar: violência, gênero e subjetividade. Cadernos Pagu, n. 37, p. 9-41, 2011.

DEIXE-ME NASCER. Rio de Janeiro: Movimento em Defesa da Vida da Arquidiocese do Rio de Janeiro, [s.d.]. Slide show para palestras. 80 lâminas.

DIREITO \& SAÚDE: O CASO DE ALAGOINHA. Rio de Janeiro: Ipas Brasil, 2010. 1 DVD (29 min).

DUMONT, L. Homo hierarchicus. São Paulo: Edusp, 1997.

DWORKIN, R. Domínio da vida: aborto, eutanásia e liberdades individuais. São Paulo: Martins Fontes, 2003.

O FIM DO SILÊNCIO. Direção, produção e roteiro: Thereza Jessouroun. Rio de Janeiro: Fiocruz Vídeo, 2008. 1 DVD (52 min).

FLORES DE MARCELA. Direção e roteiro: Glauber Filho. Fortaleza: Estação Luz Filmes, 2009. 1 DVD (23 min).

FOUCAULT, M. Os anormais. São Paulo: Martins Fontes, 2002.

HABEAS CORPUS. Direção e roteiro: Debora Diniz e Ramon Navarro. Produção executiva: Fabiana Paranhos. Brasília: ImagensLivres, 2005. 1 DVD (20 min).

HARD TRUTH. Apresentação: Gregg Cunningham. Cleveland: American Portrait Films Center for Bioethical Reform: Reel to Real Ministries, 1991. 1 VHS (9 min). 
UMA HISTÓRIA SEVERINA. Direção e roteiro: Debora Diniz e Eliane Brum. Produção executiva: Fabiana Paranhos. Brasília: ImagensLivres, 2005. 1 DVD (23 min).

KLEINMAN, A.; DAS, V.; LOCK, M. Social suffering. Berkeley: University of California Press, 1997.

LUNA, N. A polêmica do aborto e o $3^{\circ}$ Programa Nacional de Direitos Humanos. Dados: Revista de Ciências Sociais, v. 57, n. 1, p. 237-275, 2014.

NOVAES, S. C. Imagem, magia e imaginação: desafios ao texto antropológico. Mana, v. 14, n. 2, p. 455-475, 2008.

PENNA, M. L. F. Anencefalia e morte cerebral (neurológica). Physis, v. 5, n. 1, p. 95-106, 2005.

POLLAK, M. Memória, esquecimento, silêncio. Estudos Históricos, v. 2, n. 3, p. 3-15, 1989.

QUEM SÃO ELAS? Direção e roteiro: Debora Diniz. Direção de produção: Fabiana Paranhos. Brasília: ImagensLivres, 2006. 1 DVD (20 min).

RAMÍREZ-GALVEZ, M. C. Os impasses do corpo: ausências e preeminências de homens e mulheres no caso do aborto voluntário. Dissertação (Mestrado em Antropologia Social)-Instituto de Filosofia e Ciências Humanas, Universidade Estadual de Campinas, Campinas, 1999.

SALEM, T. As novas tecnologias reprodutivas: o estatuto do embrião e a noção de pessoa. Mana, v. 3, n. 1, p. 75-94, 1997.

SARTI, C. A vítima como figura contemporânea. Caderno CRH, v. 24, n. 61, p. 51-61, jan./abr. 2011.

THE SILENT SCREAM. Direção e produção: Jack Duane Dabner. Apresentação: Bernard Nathanson. Anaheim: American Portrait Films, 1984. 1 VHS (27 min). 
STRATHERN, M. Reproducing the future: essays on anthropology, kinship and the new reproductive technologies. Manchester: Manchester University Press, 1992.

VÍCTORA, C. Sofrimento social e a corporificação do mundo: contribuições a partir da Antropologia. RECIIS: Revista Eletrônica de Comunicação, Informação e Inovação em Saúde, v. 5, n. 4, p. 3-13, 2011.

Recebido em: $31 / 12 / 2013$

Aprovado em: 09/06/2014 